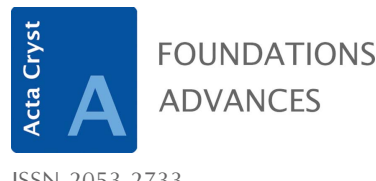

ISSN 2053-2733

\title{
Crystal Clear. The Autobiographies of Sir Lawrence \& Lady Bragg. Edited by A. M. Glazer and Patience Thomson. Oxford University Press, 2015. Pp. xx +427. Hardback. Price GBP 35.00. ISBN 978-0-19-874430-6.
}

\author{
Giovanni Ferraris*
}

Dipartimento di Scienza della Terra, Università degli Studi di Torino, Via Valperga Caluso 35, I-10125 Torino, Italy. *Correspondence e-mail: giovanni.ferraris@unito.it

Keywords: book review; Sir William Lawrence Bragg; Alice Grace Jenny Bragg.

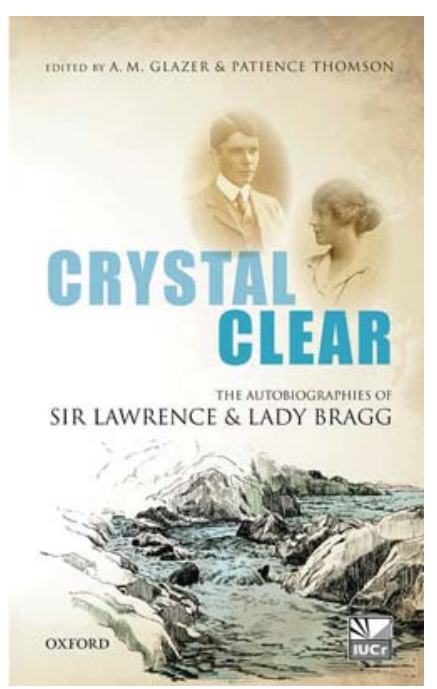

C 2016 International Union of Crystallography
This book celebrates 100 years since the Nobel Prize was awarded to Sir William Lawrence Bragg (WLB) and his father Sir William Henry Bragg (WHB): the first of a long list (at least 25) of Nobel Prizes earned by scientists exploiting Max von Laue's discovery of X-ray diffraction by crystals in 1912. The prize awarded to the Braggs also established two other records: the youngest Nobel laureate in science and the only case of father and son joint Nobel laureates. I would also like to underline that in those years crystals were for the second time the protagonist of a revolution in solid-state science: the first time was the discovery of double refraction in calcite (E. Bartholinus, 1669, and C. Huygens, 1690), an event that triggered the understanding and exploitation of the anisotropic properties of matter.

The book is an original product of Mike Glazer's longstanding interest in the Braggs, in particular in the younger one, whom he first met as a teenager and later as a $\mathrm{PhD}$ student of Dame Kathleen Lonsdale, a former student of WHB. Glazer contacted the heirs of the two Nobel laureates and, among other important documents, obtained the unknown autobiographies, now published. Obviously, Patience Thomson, the younger daughter of WLB, is an exceptional co-editor for the autobiographies of her parents.

Following an 11-page-long foreword by Mike Glazer, the book develops through three chapters: Meet Mother and Father (by Patience Thomson), where the younger daughter of WLB briefly reports her earliest memories when she was still living with her parents; in William Lawrence Bragg (In His Own Words) WLB goes through his life from his youth in Australia to the professorship at Cavendish Laboratory, stopping at 1951, shortly before his move to the Royal Institution (1954); finally, in Alice Grace Jenny Bragg 'The Half Was Not Told' Lady Bragg writes about her life up to the passing away of WLB in 1971. The book is illustrated by several valuable sketches drawn by a talented WLB, a hobby accompanying and complementing his interest in birdwatching and, more generally, offering a competent observation of nature. In the long list of his visits to universities and laboratories all around the world, WLB always managed to save a few days to explore the countryside, possibly together with his wife with whom he shared a deep love of nature.

In comparison to the autobiographies of other famous scientists, that of WLB is to some extent disappointing, at least for those interested in tracing the development of the scientific ideas and achievements of the author. In fact, whereas Max von Laue - to quote a scientist in the field of X-ray crystallography - in his autobiography gives little space to private life but covers in depth the basis for his revolutionary experiment, WLB dedicates about $50 \%$ of his autobiography to his family, including the periodic holidays and related hobbies. The scientific aspects and duties of his rich career are reported, but often without going into the background and the details that would be useful for the reader to gain a better understanding of his scientific work. Even less is dedicated to comments on people with whom he had contact, from students and co-workers, up to famous scientists.

However, by comparing the husband's and wife's autobiographies some new light can be shed on at least three controversial aspects of WLB's scientific career: his role in solving the first crystal structures, an achievement that earned him and his father the joint 
1915 Nobel Prize; the difficult relations between father and son on the matter of their contiguous researches; the 'scandal' of the book The Double Helix, where James Watson reports a very personal viewpoint of the research that brought four of WLB's 'Cavendish boys' - defined, on page 409, by Lady Bragg as the members of the team including Francis Crick, John Kendrew and Max Perutz - to elucidate the structure of DNA and, consequently, to win the 1962 Noble Prizes in Chemistry (Perutz and Kendrew) and in Medicine (Crick, Watson and Maurice Wilkins).

After getting his Honours Physics degree at Cambridge in 1912, WLB entered the Cavendish Laboratory with a research scholarship. WLB himself spoke about this crucial period (page 75 and following pages): 'After 1 year my golden opportunity came. Von Laue published his paper on diffraction of X-rays and my father discussed it with me. [In Leeds] I set up an experiment in my father's laboratory to test whether the spots seen in von Laue's photographs which he ascribed to diffraction might really be due to neutral particles [as his father believed]. I continued to mull over von Laue's results and soon convinced myself that they must be due to diffraction. My next advance was an interesting example of the way in which apparently unrelated bits of knowledge click together.'

The crucial 'bit of knowledge' mainly consisted of Pope and Barlow's theory of crystal structure bringing for 'the first time the idea of a crystal as regular pattern' to WLB, who describes his enlightenment as follows: 'I can remember the exact spot on the Backs where the idea suddenly leapt into my mind that von Laue's spots were due to the reflection of X-ray pulses by sheets of atoms in the crystals.' Finally he writes: 'it was my father who announced the new results at the British Association, the Solvay Conference and at lectures up and down the country in America, while I remained at home. My father more than gave me full credit for my part, but I had some heartaches.' A postcard signed by the Gotha of scientists attending the Solvay Conference and sent to WLB is reproduced in the book.

I would like to note the striking similarity of the paths followed by W. L. Bragg and M. von Laue to gain their belief about the behaviour of X-rays in crystals. The latter, in his autobiography, recalls that he, who knew little of crystallography, was inspired by the structure models of L. Sohncke and writes the following after having seen the diffraction patterns obtained by W. Friedrich and P. Knipping: 'I was plunged into deep thought as I walked home. Not far from my own apartment, the idea for a mathematical explanation of the phenomenon came to me.'

To avoid further heartaches, father and son tried to keep their research separate, as far as it was possible given they were working in the same field. On this matter Lady Bragg writes the following (page 340): 'Much has been said and even written in later years about my father-in-law, and my husband's relations with him over their research work. I am myself inclined to think that difficulties which were inevitable and natural have been exaggerated. In the case of Sir William, he really came to think that some idea of WLB's was his own; or WLB would tell him about a special line of research, and his father, later, would think about it himself and might see a further development. At any rate, some visits of ours were rather spoilt by this situation.'

In her autobiography Lady Bragg also throws some light on the unpleasant situation created by J. Watson's book The Double Helix and writes: 'I was appalled: so many of those people that he had met in his host country, and especially in Cambridge, were held up for criticism and ridicule, and none more than his professor, WLB.' At variance to a version of the facts reported in an interview published by The Observer on Sunday 9 December 2012 where Watson affirms that 'he [WLB] was persuaded by Lady Bragg, who had enjoyed the book, to change his mind,' Lady Bragg continues as follows: "Jim Watson asked WLB to write the introduction and to my amazement, he accepted. I recall standing with the two men in the hall of our flat, and Jim saying that he hoped that I realized that there was no one he admired more than my husband. I was annoyed. 'No one could possibly think that after all the horrid remarks you made about him in your wretched book,' I said angrily. The introduction was duly written and I was pleased at the many messages WLB received paying tribute to his magnanimity. He had written gently at the end: 'Those who figure in this book must read it in a very forgiving spirit."”

Some footnotes of the editors to connect the husband's and wife's viewpoints on the same facts would have been a useful guide for readers. The content of the book is of certain interest to scientists, historians of science and to those interested in the life of a bourgeois British family in the first half of the 20th century (I at least appreciated this), an aspect well depicted in both autobiographies, but particularly through the captivating prose of Lady Bragg. 